\title{
THE VULNERABILITY OF THE SACRAL LANDSCAPES IN BUKOVINA
}

\author{
DOI: http://dx.doi.org/10.18509/GBP.2019.53
}

UDC: 930.85:726.54(498.3)

\author{
Divisevici Ana Maria ${ }^{1}$ \\ ${ }^{1}$ Stefan Cel Mare University, Faculty of History and Geography, Suceava, Romania
}

\begin{abstract}
The paper emphasizes the dissolution of the cultural value of some important landmarks, components of the sacral landscapes from the south-easten part of the historical province of Bukovina. The transformation of the sacral landscapes in the last 100 years has been was the consequence of historical and political pressure. One of the most disturbed components of the sacral landscapes was the degradation of the medieval monasteries frescoes. This dramatic threat was in this particular case, the result of several unfortunate restoration processes or the lack of interest for the cultural values.
\end{abstract}

Keywords: sacral landscape, vulnerability, Bukovina, Arbore church, St.George Church

\section{INTRODUCTION}

The cultural landscapes are a result of a complex evolution depicted from the physiognomic diversity of surface, interlinked with the intensity of exchange of matter, energy and information between the natural and anthropogenic components that takes a certain evolution in time. The geographical landscape's transformation expresses the anthropogenic intervention of the environment by associating the subjective cultural elements, recognizing therefore the increasing human capacity to remodel the nature.

The cultural landscape is viewed as a mosaic of spatial elements, organized in a hierarchical components, dynamics, interconnections, characteristics and a specific structure with an evolution directed by the human factor [1].

The sacral landscape as a division of the cultural landscape in time occurrence and evolution is related to the material manifestation of human intervention on natural landscape.[2].Moreover, human contributions to the transformation of the sacral landscape were achieved gradually and as a result of actions taken by people in order to fulfill their spiritual needs.

The sacral landscape acts as a cultural landscape incorporating elements with a dominant spiritual role such as church or monastery and sub-assemblies for example, cemeteries, standing wooden crosses etc. with a specific structure and functionality within each local community.

The theoretical basis through which the sacral landscape is defined implies classification and characterization involving practical attributes consisting in a multiple opportunities for conservation and enhancement, in relating with these aspects, the sacral landscape can be graded according to the degree of vulnerability.

Generally, this type of cultural landscape reflects a high degree of conservation, explained by the fact that the entire local community is involved both materially and spiritually.

Especially in the case of St. George -Suceava and Arbore churches, in a particular way the dynamic trajectory reveals different stages of involution, or a certain degree of vulnerability caused by the particular social and cultural factors of each sacral landscape. The high vulnerability is related to the constant aging process and deficiency of interest 
from the local community, or from the state authorities, even though, both churches are included on the UNESCO List of World Heritage Sites.

\section{STUDY AREA}

The south part of Bukovina is now overlapping almost entirely with Suceava county. Bukovina or the Beech Country has been part of the Principality of Moldavia until 1774, when it was annexed to the Austrian Empire by force. In 1849, the area was appointed the name of Duchy of Bucovina and from 1867 and 1918, it was an independent province of Austro-Hungary. Bukovina reunited with Romania in 1918, after the Great War (World War I) but after 1940 the Soviets occupied its north area, between the Prut and the Nistru.[3] Bukovina in its dynamic evolution is powerfully contoured on the cultural map of Romania, pinnacles through its values with a large spiritual and material heritage, with its one style and unified by cultural assets, wealth and diversity.

This land is widely known for its unique landscapes, for its storied history, its reputation for legend and multitude of monasteries and exterior frescoes, which continues to draw awed attention with vivid natural colours that have lasted through centuries. Eight of these monasteries have received particular recognition for their uniqueness and artistic value. In this article we present the dynamic of two of the most representative and valued churches -one located in a rural area, the old orthdox church built in the -XVI- century in the Arbore village, situated at the $36,8 \mathrm{~km}$ form the main city Suceava and another one, the St. George Church situated in the center of Suceava city.[fig.1]

\section{METHODOLOGY}

The methods and means for the present research were based on general techniques such as observation, analysis, synthesis, comparison, historical method, classification etc along with particular methods specific to the cultural geography and cultural landscape interpretation as the component register method.The Landscape Component Register includes the elements specific to the given space, including information on functionality, use, dimensions, attributes, value, evaluation criteria, geographical coordinates, etc. for a certain type of landscape, as in the Glink C. Meyer, Schottke pattern. [4], [5]

A particular approach is offered by the aesthetic interpretation in relation to the quality image of the mural painting which has a major role in transmitting the artistic message.

\section{RESULTS AND DISCUSSION}

The feature of the two sacral cultural landscapes, the St. George Church in Suceava.[6] and the Orthodox Church of Arbore [7] permits the classification and integration in the large hierarchy based on qualitative, functional and quantitative criteria.

We have traced the evolution of sacral landscapes under the direction of positive and negative social historical events that marked the temporal dynamics for the two iconic sacral landscapes. We have identified the elements that individualize them, determine the position and the degree of visibility, the intensity in functionality, the conservation and vulnerability level.

The mural Byzantine painting that covers the walls of most of the medieval churches in Bukovina with an inestimable cultural value has been damaged in time over a period of nearly 500 years.

The factors that contributed to the sacral cultural landscapes dynamics in time are natural and human. 
a.The natural factors have a positive or a negative effect. The manifold positive natural factors includes the presence of Suceava Plateau, with a continental temperate climate with cold tendencies, numerous rivers, with large areas of forests, which favoured the development of human settlements in the region. The negative aspects of the natural factors are the high humidity, moore than $60 \%$ in the case of Arbore church, that favours the rapid degradation of the old medieval constructions, by producing microorganisms causing the appearance of the harmful patina and a rapid degradation of painting pigments, blackout or discoloration.

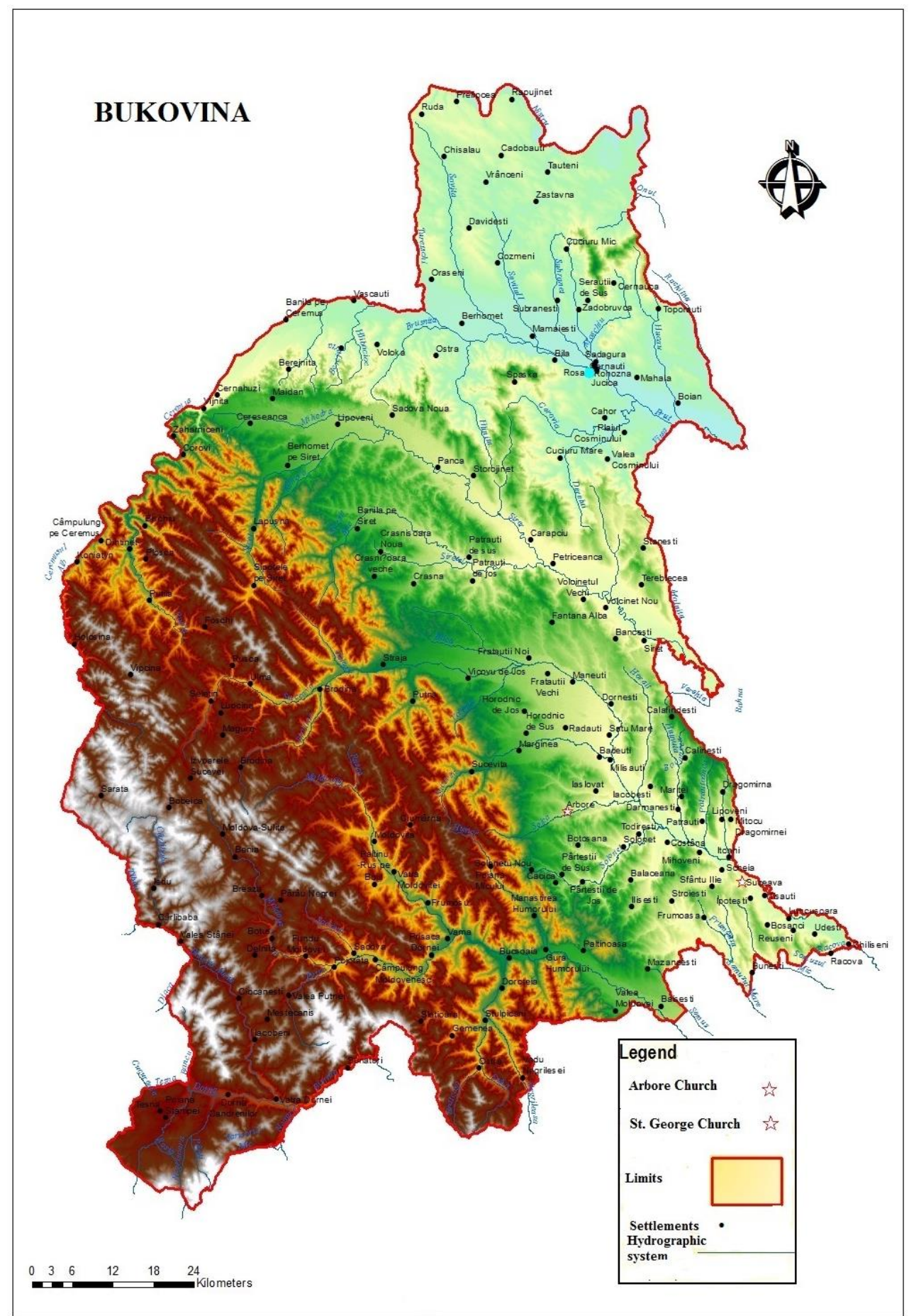

Figure 1. The geographical map of Bukovina- the location of the Churches of St. George and Arbore 
b.The anthropological factors consist in a large range of historical and political conditions that influenced the evolution of Bukovina such as the invasion of the Turkish, Russian, Polish, Austrian and Soviet military troops, or the pressure of the antireligious measures perpetrated by the communists.

The scratches and incisions over the a fresco painting inside the churches of St.George in Suceava [fig.2] and Arbore which are very common, were first made by the monks, then by the parishioners, the invaders, the tourists or the evil intentioned persons.[8]

In the case of St. Gheorghe in the nave, in the south part the damaged engravings are visible even after numerous attempts of restoration. A conclusive example of the destructive effect is the extended surface incisions and scriptures over the fresco over the stage of The Baldachin Offering made by the Polish soldiers. Other incisions mentioned the year in which the holly relics were grabbed in 1686, but also the year of their return, 1783

As a cultural turn, these initially harmful inscriptions are now the subject of scientific discussions, specialists considering these aggressions on mural paintings as documentincisions to be studied by epigraphists and historians, offering the ability to reflect, associate and analyze.[8]
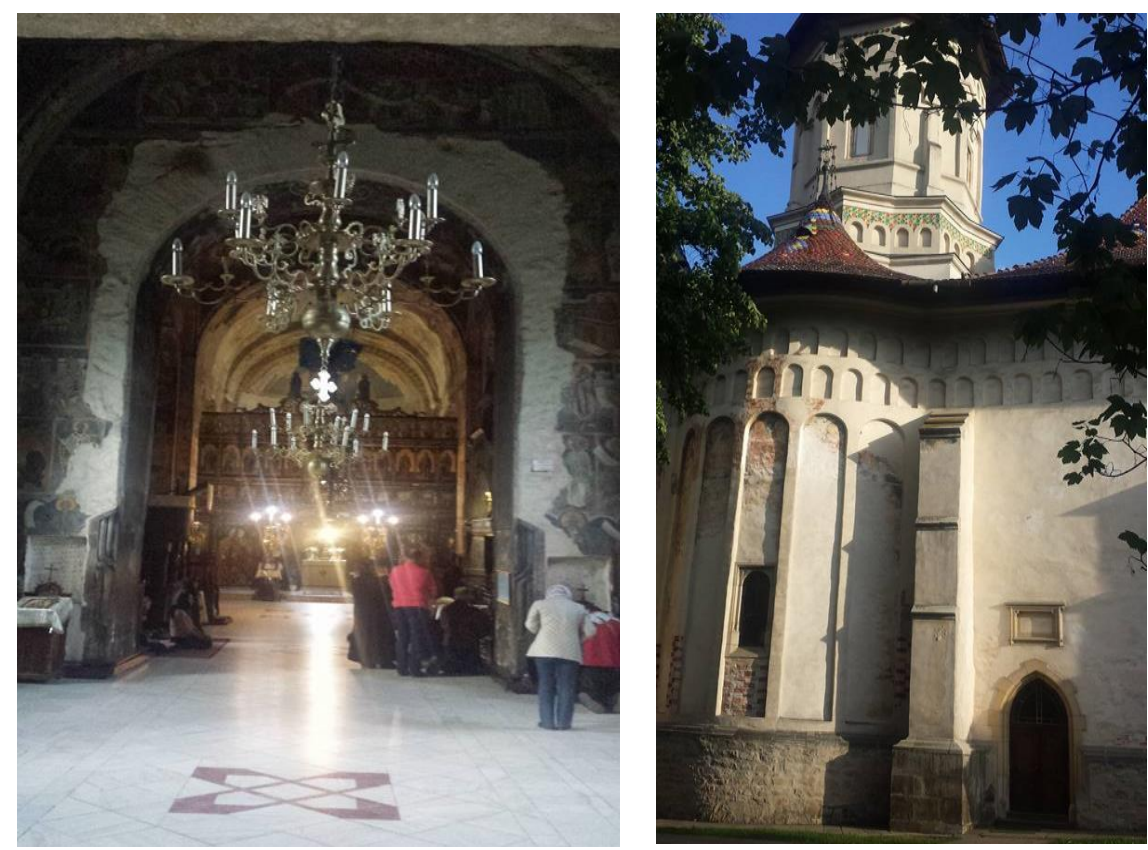

Figure 2. St. George Church- the nave and the North façade Photo by author

In the case of Arbore church the most of the scraps were produced on the exterior frescoes at the base of the building.

Another human factor is illustrated by the modifications made to the original painting by re-painting that led to the degradation and falsification of authentic images.

The Arbore Church was repainted several times in the last 500 years, in 1845, 1887 and 1980 for the purpose of covering the traces of vandalism. The restoration made by Ion Bodnarescu in 1887 through personal additions and re-interpretations produced a diminuation of the Byzantine stylistic value and the irreversible destruction of some painted scenes. The icon placed in the upper part of the exonartex entrance of the spiritual patron of the church, St. John the Baptist was repainted in 1845.[Fig.3] The new image 
received the influences of the neorealistic style, characteristic of that period, the original painting unfortunately was not understood and appreciated being completely over covered, but through the meticulous work of restorers the original image could be recovered.

The degradation over time due to the lack of interest in preserving a fresco mural painting from the local and national authorities is another negative anthropic factor. The limitation of religious expression in Romania after 1945 and the submission of Orthodoxy in general by the systematic destruction of monasteries and churches from the Communist Party were triggered by 410 Decree issued during communist leader Gheorghe Gheorghiu -Dej. The anti-religious policy had increased since 1960 and had led to the degradation of the religious functionality of places of worship due to the forced closure of many churches and monasteries. Many of the fresco churches in Bukovina were abandoned, thus finding themselves subject to an accelerated degradation process

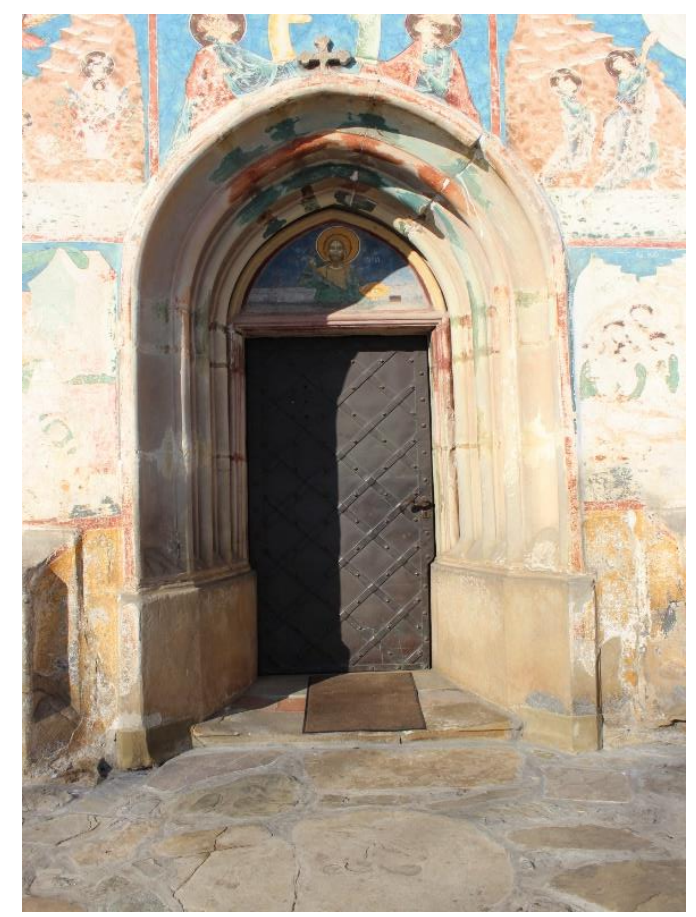

Figure 3. Arbore Curch- above the main entrance in Gothic style, there is the icon of St. John the Baptist nowadays in the stage of re-restoration Photo by author

At the Church of Arbore village [fig.4], the roof degradation was favoured by a series of convergent forms of destruction, which eventually led to the irreversible alteration of the color layer and to the over $60 \%$ total loss of exterior mural painting. The northern facade is completely erased due to structural deterioration, masonry cracks, defective pluvial collection system and the very high humidity in the immediate vicinity that favoured infiltration. An equvalent process took place to the northern face of St. George's church in Suceava.

Economic and industrial factors had played an important role in the acceleration of the pollution phenomenon and favourised the mural paintigs degradation. A major role was given to the polluting factories that functioned during the communist period such as the chemical cellulose and paper plant from Suceava. 
Poor restorations have contributed to the acceleration of the degradation process, requiring careful interventions by specialists, reconstruction of the painting layers, restoration of pigments from original colours or consolidation of the church walls. [Fig5] After the end of the restoration interventions which started in 1980, as an emergency restoration initiative, both churches underwent many other stages. The restoration program ended right after 2004, when the unique elements of great value and originality were reinstated that previously had been hidden to the viewer. [9]
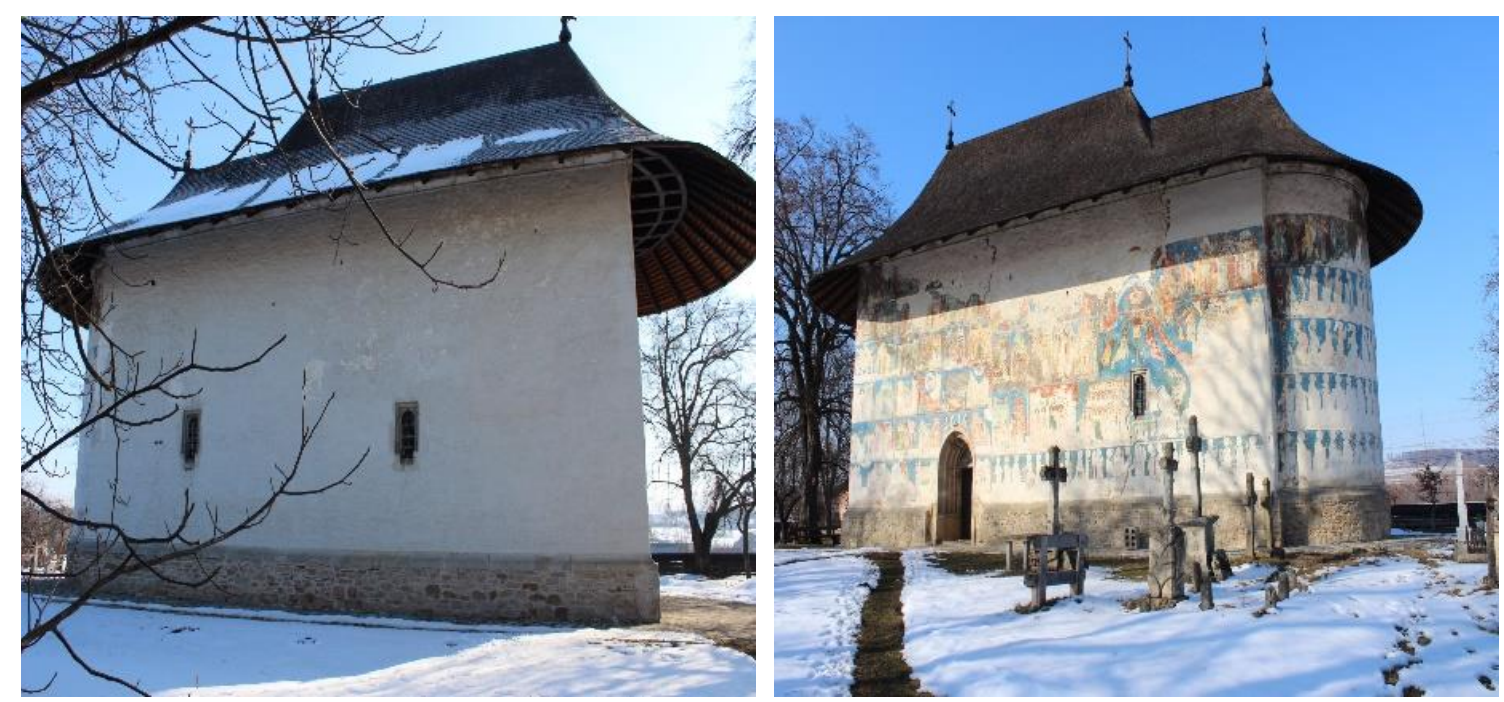

Figure 4. the northern and southern facade of Arbore Church Photo by author

Other factors that have contributed to the degradation of the sacred landscape are related to the religious functionality. Influences of the religious service of worship are regarded as forms of unintentional degradation. They produced due to agglomeration of people the effect of microclimate variations that led to the generation of the dew point and the appearance of water droplets on the surface of the paintings. The combustion produced by the candles creates tar and smoke particles that are deposited on the painting causing the radical change of the colors by chemical transformation of the pigments and in the end the blackout frescoes.
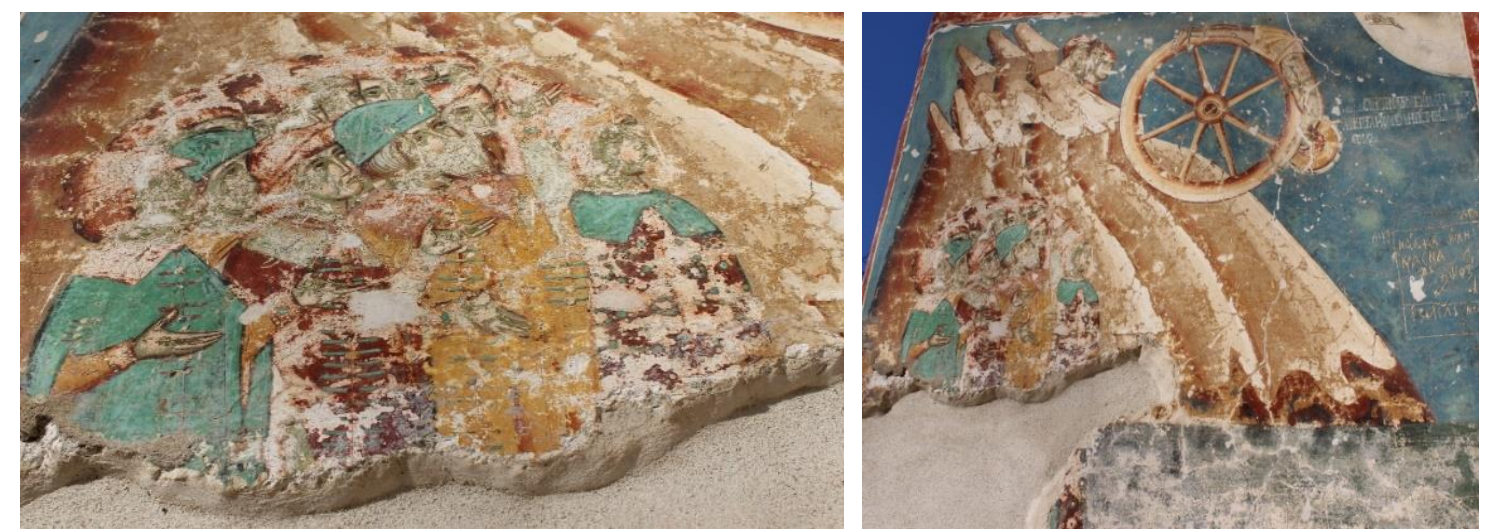

Figure 5 Arbore Church -Detail from the Western façade. Even if it is in an advanced stage of decay, the murals express the extraordinary technical mastery of the painters

Photo by the author 
In the systemic evolution of the cultural landscape in particular the sacral one, there are several stages and in some of them there are possible manifestations of instability.[10] The vulnerability is expressed by the predicted degree of exposure to certain risks under the pressure of various factors.

The vulnerability derives from the probable degree of exposure to certain risks under the pressure of various factors. It is characterized by the low self-regulation ability of the sacral cultural landscape as a system, and by the inability to annihilate the disturbance factors. In the case of the two churches, Arbore and St. George we can identify some challenges that have contributed to the production of some favourable or unfavourable changes in the evolution of sacral landscape components with a prominent role, such as the condition of the Byzantine frescoes.

\section{CONCLUSION}

It is possible to identify three stages from the perspective of estimating the degree of vulnerability;

1. Relatively stable sacral cultural landscapes - are the ones in which the preservation of values and functionality have taken place, through the involvement of local leaders and of the community members. Here can be included in this category the monasteries and churches from Bukovina that were completely and successfully restored. Beyond and their religious functionality, the touristic one was also added such as in the case of famous Voronet monastery or the church of St. George

2. Sustainable sacral cultural landscapes that are capable of maintaining their dynamics- like cemeteries or recently built churches

3. Vulnerable sacral cultural landscapes, subject to the conditioning of unfavourable factors- such as from the present paper, Arbore Church.

From the perspective of the degree of vulnerability, a distinction is clearly observed between the two churches generated by a series of characteristics.

In the case of the Arbore Church, the degree of vulnerability is more increased than in the St. George Church case:

- The Arbore Church is poorly preserved, less prominent in the hierarchy of sacred landscapes in Bucovina.

- Unlike St. George's Church in Suceava, the Church of Arbore is much smaller in dimensions, less frequented by visitors, with partial functionality due to temporary religious service and with reduced tourist purpose because of its advanced stage of deterioration.

- The urban St. George church, is centrally located, being one of the most frequented churches. It has an important functionality, which was meant from the beginning to serve as the new Metropolitan Cathedral of Moldavia replacing the old church of Mirauti.

- This position determined the choice of the architectural type considered to be most adequate for the solemn services.

The diversity of the changes in society manifests itself through the reflections in the physiognomy, the structure and the functionality of the Bucovina's sacral landscapes, thus determining the enhanced study in identifying the possibilities of maintaining an optimal systemic balance. 


\section{REFERENCES}

[1] Camelia Ina-Gavra -Peisajul cultural, tipologia peisajului cultural, in Terra, Anul XLIII,(LXIII), Nr. 1-2, Editura CD Press, București, 2012, p167-168

[2] Camelia Ina- Gavra- Peisaje culturale in Muntii Metaliferi Editura RISOPRINT, Cluj-Napoca, Romania, 2013, p57

[3] *** Suceava County Council-Bucovina- Little Europe, Editura Lidana, Suceava -Romania 2015,p 6-10,

[4] C. Glink, H.H. Meyer, Schottke, Maya-Historical Cultural Landscapes in Romania, in Romanian Review of Regional Studies, vol. III, Nr 2, Ed Presa Universitară Clujeană, Cluj Napoca, 2007 p48-56

[5] C. Glink, H.H. Meyer, Schottke, Maya-Catalogue and Register of Cultural Landscape Elements, In Infrastructure and Ecology of Rural Areas, Cultural Landscape. Protecting Historical Cultural landscapes- Ed. Polish Academy of Sience, Cracow, 2008, p 11

[6] Nicolaie Vornicescu-Biserica Sf Mare Mucenic Gheorghe din Suceava, Ed. Mitropoliei Moldovei şi a Sucevei, Iași, 1974, p10-34

[7] Ion Solcanu Datarea ansamblurilor de picture murală de la biserica Arbure, in Anuarul Institutului de istorie și arheologie A.D Xenopol, vol XII, 1975, p 2-8

[8] Oliviu Boldura- Pictura Murala din Nordul Moldovei. Modificari estetice si restaurare, Ed. ACS, Bucuresti-Romania, 2013 p. 120-144,

[9]Tereza Sinigalia \& Oliviu Boldura-Medieval Monuments of Bukovina, Editura ACS, Bucuresti-Romania, 2010, p. 47-57

[10] Liviu Drăguț -Geografia Peisajului, Ed Presa Universitară Clujeană, 2000, p.4-23 